\title{
Air pollution in post-COVID-19 world: the final countdown of modern civilization?
}

\section{Comment on: "COVID-19 and air pollution: the worst is yet to come"}

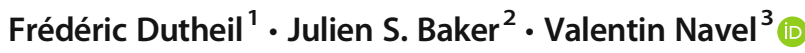 \\ Received: 20 April 2021 / Accepted: 11 May 2021 / Published online: 17 May 2021 \\ (C) The Author(s), under exclusive licence to Springer-Verlag GmbH Germany, part of Springer Nature 2021
}

\section{To the Editor:}

One year ago, we described the unprecedented decrease of air pollution during the first global lockdown (Dutheil et al. 2020a). Due to the COVID-19 crisis, most governments closed their borders and airports, limited the external market, and reduced their industrial production to avoid SARS-CoV-2 spreading (Dutheil et al. 2020b). The first global lockdown of Spring 2020 induced the first decrease period of air pollution until industrial revolution. Humanity lived in healthy atmosphere during 8 months, approximately from February to September 2020 (European Space Agency (ESA) n.d.-a). At this time, we considered several published models to predict mortality due to air pollution (i.e., increase of all-cause mortality ranging from $0.13 \%$ per $10 \mu \mathrm{g} / \mathrm{m}^{3}$ of nitrogen dioxide $\left(\mathrm{NO}_{2}\right)$ per day to $2 \%$ per $10 \mu \mathrm{g} / \mathrm{m}^{3}$ of $\mathrm{NO}_{2}$ on a 5 -day period) (Chiusolo et al. 2011; Hoek et al. 2013; He et al. 2020). However, at the end of the first waves of SARS-CoV-2, most countries quickly increased their greenhouse gas emissions to revitalize the global market and avoid market collapse. At the time of writing, the world is living with COVID-19 pandemic

Responsible Editor: Philippe Garrigues

Frédéric Dutheil

fdutheil@chu-clermontferrand.fr

1 Université Clermont Auvergne, CNRS, LaPSCo, Physiological and Psychosocial Stress, CHU Clermont-Ferrand, University Hospital of Clermont-Ferrand, Preventive and Occupational Medicine, Witty Fit, F-63000 Clermont-Ferrand, France

2 Centre for Health and Exercise Science Research, Department of Sport, Physical Education and Health, Hong Kong Baptist University, Kowloon Tong, Hong Kong

3 Université Clermont Auvergne, CNRS, INSERM, GReD, Translational Approach to Epithelial Injury and Repair, CHU Clermont-Ferrand, University Hospital of Clermont-Ferrand, Ophthalmology, F-63000 Clermont-Ferrand, France until 1 year, cumulating more than 125 million of cases and 2.8 million of deaths. Despite of several worldwide plan to reduce the spreading of SARS-CoV-2 (i.e., global quarantine, social restrictions, vaccination plan), numerous worldwide countries currently undergo a third wave of contagion. This alarming situation is increased by the high rate of SARS-CoV2 mutations, and rare but severe iatrogenic reactions with several vaccines, limiting their acceptance in general population (Turner et al. 2021; Carli et al. 2021). From October 2020, the levels of $\mathrm{NO}_{2}$ and monoxide carbon (CO) increased worldwide, with alarming concentration compared with levels before the COVID-19 pandemic (Fig. 1) (European Space Agency (ESA) n.d.-a); European Space Agency (ESA) n.d.b). The impact of air pollution is not only a problem of western countries, but particularly affects developing countries: 193,000 European people died in 2012 from airborne particulate matter and 4000 preventable deaths each day in China with 1.6 million fatalities in 2016 (Wang et al. 2012; Rohde and Muller 2015; Ortiz et al. 2017). It is well-known that airborne particulate matter and radical species due to fossil fuel exhausts induce asthma, bronchitis, emphysema, lung and heart diseases, and respiratory allergies (Brauer 2010). To quickly restart the economic machine, most countries burn fossil fuel and continue to exploit coal mines, engulfing the world in ecological disaster. To memory, the Paris Agreement was adopted by 196 countries at COP 21 in Paris, on 12 December 2015 , to limit global warming to below $2^{\circ} \mathrm{C}$. While COVID-19 crisis will probably finish in 2022-2023 with an unprecedented mortality rate, we could ask to future young generations: "Post-COVID-19 world is it made for you?" In massively decreasing the greenhouse gas emissions during few months, the COVID-19 crisis could be described as "COVID-19 paradox" in the history of Anthropocene: a global survive of modern civilization against viral pandemic, in accelerating their future extinction due to climate change. Even if the needs of robust global economy are vital for the 

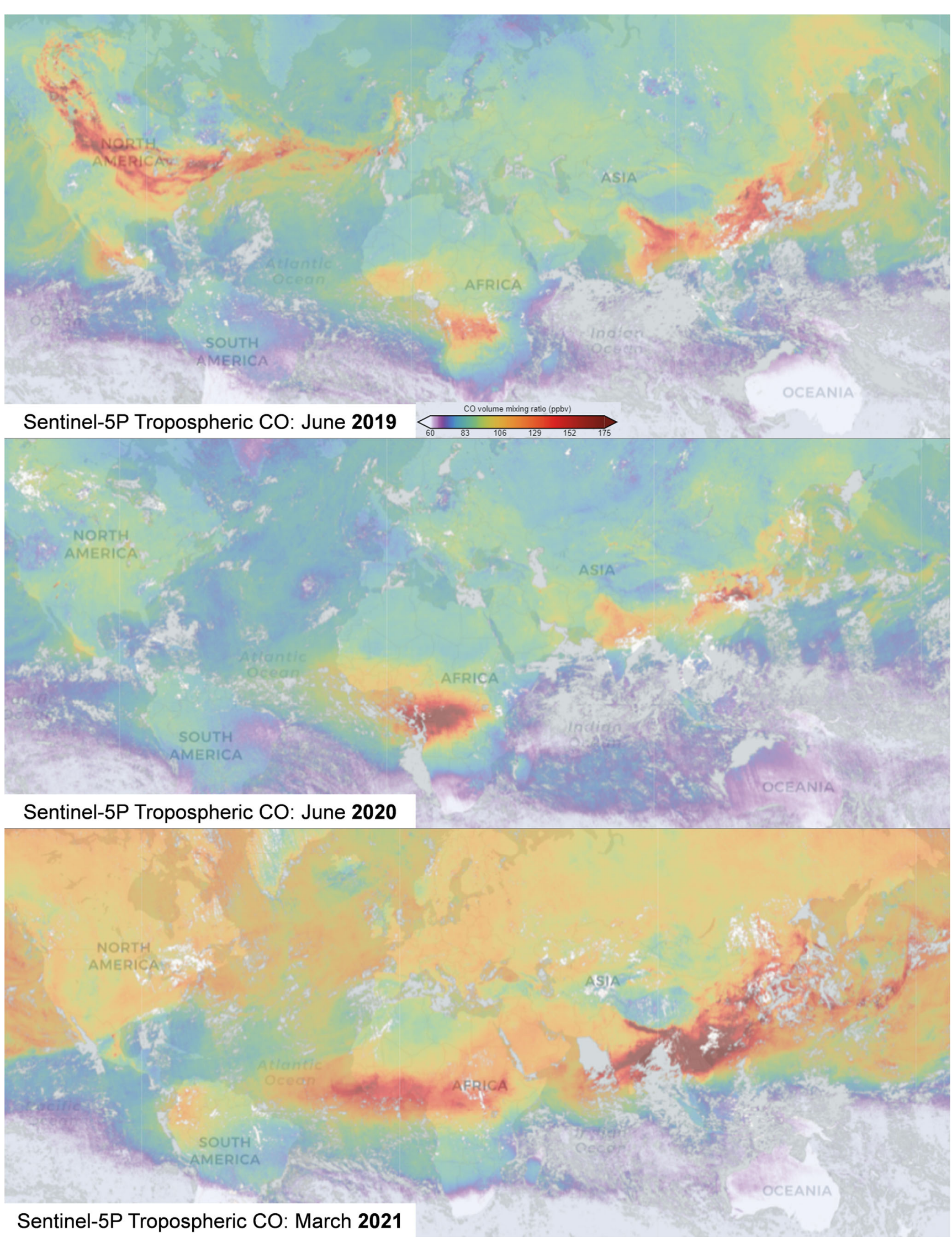
Fig. 1 Maps of tropospheric CO concentrations from Copernicus Sentinel-5P satellite (European Space Agency (ESA) n.d.-b). The averaged carbon monoxide concentrations across the globe were described as 3-day moving average

needs of humanity (science, health, food resources), it seems to be valuable to consider our planet as the first precious resource rather than short-term concerns.

\section{Declarations}

Conflict of interest The authors declare no competing interests.

\section{References}

Brauer M (2010) How much, how long, what, and where: air pollution exposure assessment for epidemiologic studies of respiratory disease. Proc Am Thorac Soc 7:111-115. https://doi.org/10.1513/ pats.200908-093RM

Carli G, Nichele I, Ruggeri M, Barra S, Tosetto A (2021) Deep vein thrombosis (DVT) occurring shortly after the second dose of mRNA SARS-CoV-2 vaccine. Intern Emerg Med 16:803-804. https://doi.org/10.1007/s11739-021-02685-0

Chiusolo M, Cadum E, Stafoggia M, Galassi C, Berti G, Faustini A, Bisanti L, Vigotti MA, Dessì MP, Cernigliaro A, Mallone S, Pacelli B, Minerba S, Simonato L, Forastiere F, on behalf of the EpiAir Collaborative Group (2011) Short-term effects of nitrogen dioxide on mortality and susceptibility factors in 10 Italian cities: the EpiAir study. Environ Health Perspect 119:1233-1238. https://doi. org/10.1289/ehp.1002904

Dutheil F, Baker JS, Navel V (2020a) COVID-19 and air pollution: the worst is yet to come. Environ Sci Pollut Res Int 27:44647-44649. https://doi.org/10.1007/s11356-020-11075-6
Dutheil F, Baker JS, Navel V (2020b) COVID-19 as a factor influencing air pollution? Environ Pollut 263:114466. https://doi.org/10.1016/j. envpol.2020.114466

European Space Agency (ESA) (n.d.-a) Global air pollution maps now available

European Space Agency (ESA) (n.d.-b) Copernicus Sentinel-5P carbon monoxide

He MZ, Kinney PL, Li T, Chen C, Sun Q, Ban J, Wang J, Liu S, Goldsmith J, Kioumourtzoglou MA (2020) Short- and intermediate-term exposure to $\mathrm{NO} 2$ and mortality: a multi-county analysis in China. Environ Pollut 261:114165. https://doi.org/10. 1016/j.envpol.2020.114165

Hoek G, Krishnan RM, Beelen R, Peters A, Ostro B, Brunekreef B, Kaufman JD (2013) Long-term air pollution exposure and cardiorespiratory mortality: a review. Environ Health 12:43. https://doi. org/10.1186/1476-069X-12-43

Ortiz C, Linares C, Carmona R, Díaz J (2017) Evaluation of short-term mortality attributable to particulate matter pollution in Spain. Environ Pollut 224:541-551. https://doi.org/10.1016/j.envpol. 2017.02.037

Rohde RA, Muller RA (2015) Air pollution in China: mapping of concentrations and sources. Berkeley Earth

Turner PJ, Ansotegui IJ, Campbell DE, Cardona V, Ebisawa M, el-Gamal Y, Fineman S, Geller M, Gonzalez-Estrada A, Greenberger PA, Leung ASY, Levin ME, Muraro A, Sánchez Borges M, Senna G, Tanno LK, Yu-Hor Thong B, Worm M, WAO Anaphylaxis Committee (2021) COVID-19 vaccine-associated anaphylaxis: a statement of the World Allergy Organization Anaphylaxis Committee. World Allergy Organization Journal 14:100517. https://doi.org/10.1016/j.waojou.2021.100517

Wang H, Dwyer-Lindgren L, Lofgren KT, Rajaratnam JK, Marcus JR, Levin-Rector A, Levitz CE, Lopez AD, Murray CJL (2012) Agespecific and sex-specific mortality in 187 countries, 1970-2010: a systematic analysis for the Global Burden of Disease Study 2010. Lancet 380:2071-2094. https://doi.org/10.1016/S0140-6736(12) 61719-X

Publisher's note Springer Nature remains neutral with regard to jurisdictional claims in published maps and institutional affiliations. 